\title{
The Level of Multiple Intelligences of Deaf Adult Students at Al-Ain University and The University of Tabuk
}

\author{
Dr Ziyad Kamel Ellala, Dr. Jamal H. Abu-Attiyeh , Dr.Tar Abdallahi \& M.A. Naim Momani \\ Al Ain University, Faculty of Education, Humanities, and Social Sciences \\ Dr. Mohamed Ismail Abu Shaireh, University of Tabuk
}

Article History: Received:11 January 2021; Accepted: 27 February 2021; Published online: 5 April 2021

\begin{abstract}
The study aimed to identify the level of multiple intelligences among deaf adult students, attending both Al-Ain University and the University of Tabuk from their point of view in the light of multiple variables (including sex, university, employment). The study sample consisted of 82 deaf students divided among two groups. Thirty two (32) students were from Al-Ain University distributed 12 ) Student ) 11 (student. From Tabuk University fifty (50) students were distributed into two groups of students numbering (23) and (27) respectively. To achieve the objectives of the study a scale developed by researcher Walter Mackenzie (Mackenzie, 1999) was used. The scale scans multiple intelligences; included on the scale was eighty (80) statements distributed over eight (8) areas, where each area represents a kind of multiple intelligence. To derive results, the mean, standard deviations and a T-test were used to answer the designated study questions.
\end{abstract}

The Study Results showed c and d differences D of the self/inner intelligence, verbal/linguistic intelligence, social/external intelligence, visual/spatial intelligence, and

the total score of the scale was in favor of females. There were no significant differences in other areas depending on the variable sex (male, female). The results showed there to be significant differences in the field verbal intelligence/linguistic to the benefit of deaf adult students at Tabuk University in Saudi Arabia. There was no significant differences in the other fields according to the university variable, Al Ain for Science and Technology and Tabuk. The results showed that there were statistically significant differences according to the emloyment condition variable in the intelligence fields verbal/linguistic, social/external, natural intelligence/environmental, physical/motor and musical/rhythmic) in favor of non-staff. The absence of significant differences was found in the rest of the areas depending on the variable employment (employee, non-employee). The study came up with several recommendations.

Key words: Multiple Intelligences, Deaf

\section{Introduction and theoretical framework:}

In the last decades of the twentieth century, the educational system was characterized by a bet on quality education. The focus was on developing the potential of the learners and their mental abilities in the best possible way after confirming the importance of human wealth in the progression and advancement of society as the most important developmental resource. This great interest in the human mind, its potential, and its development undoubtedly highlights the distinctive educational system at the beginning of the third millennium. It is a system that strives to enlighten and nurture the minds of the learners to meet the aspirations of their societies and to play an active role in the post-industrial society. It requires of the individual a high degree of cognitive adaptation (Hala, 2015).

In order to achieve this, efforts have catered towards various methods of planning, curriculum development, and have built upon the results of scientific data for studies of contemporary psychology, particularly in the cognitive psychology subfield. The research was accompanied by the development of curricula, analysis, and study of learning mechanisms. Two psychological theories were known to explain the reasons for the differences among students in learning methods described in: learning method theory and multiple intelligence theory. If the first theory is rooted in psychoanalysis, the second theory is the product of research in knowledge science (Hussein, 2005) (Shami, 2008).

The theory of multiple intelligences has since revolutionized educational practice. It has changed teachers' perception of their students and has become the appropriate method of educating them according to their individual intellectual abilities. This theory has also posed a challenge to the traditional concept of intelligence as remaining constant in the individual at different stages of their life. Educators have welcomed the theory of intelligences difference among people in the types of intelligences that they have and in the method of use. The insight contributes to the enrichment of society and the diversification of culture and civilization by making room for each type of the eye And crystallization in production that benefits the development and progress of society (Kienzler, 2001) (Obaidat, Abu Al-Semaid, 2005). 
The theory of multiple intelligences emerged in 1983, when Howard Gardner first presented in his book The Frames of the Mind, the existence of multiple and distinct intelligences (Gardner, 1983 Sentences, et al., 2003). Gardner reached his theory by conducting numerous medical researches on the human brain. He studied and documented the remaining capabilities of those patients who had had a damaged part of their brain which has been adopted in the formulation of his theory. Two basic factors are:

1. Fixed information on developing the different skills of ordinary children.

2. How these skills are lost as a result of brain injuries.

He concluded that if the brain is somehow damaged, the individual may lose some skills or retain some skills in isolation from other skills. The brain has been studied on different cognitive styles such as those seen in geniuses and gifted students, and those seen in students with learning disabilities. Each of these categories is considered a different pattern of thought and is difficult to explain in the light of a theory of just one IQ. He proposed his Theory of Multiple Intelligences where he concluded that an individual has a number of discrete capabilities, which may interact to serve one another or they may work alone when it comes to other capabilities. These capabilities or intelligences are categorized in nine (9) suggested types, each of which may be the center of creative abilities (Musharraf, 2003) and (Amer and Muhammad, 2008).

The practitioner using educational data previously restricted Bnzertha intelligence; where the intelligence of the learner is considered a single, unified capability that can be summarized or expressed through a particular scored number value known as "IQ". This traditional view of intelligence is considered to be limited in terms of mental abilities that are measured or relied upon in determining the level of intelligence of a child. These abilities fall under the categories of language and mathematics. The two areas overshadowed the traditional school programs and curriculum making it difficult to fulfill the needs of those students that may be weak in language or mathematics.

In response to this narrow perspective, it has emerged in recent years through many studies and theories such as those by Sic and Wajih which shows very clear support for the fact that human intelligence involves multiple skills. This necessarily calls for school systems to review their methodologies in dealing with various learners. Schools need to take into account the different capacities students have and not to only focus on language skills and sports. Perhaps the most significant of these theories is the theory of "multiple intelligences" developed by American researcher Howard Gardener

(Gardner, 1983)

and

(Zaki, 2000).

Multiple intelligences:

Gardner (1987) defines intelligence as a set of capabilities that are somewhat independent of other human capacities and as having a system of information processing. These intelligences have a specific date in the stages of development through which each of us pass and have their roots in the history of honest development. Gardner believes that success in life requires a variety of different intelligences, and decides that the most important contribution that education can make to the development of learners is to guide them to areas that suit their excellence. It is in those areas of intelligence that they achieve satisfaction and fulfillment. Intelligence is something that can be measured objectively and that the brain is divided into nine (9) intelligence types.

1) Linguistic Intelligence: The ability to produce and use language to express ideas, understand abstract analyses, symbolic thinking, concepts, and literature.

2) Logical/Mathematical Intelligence: The ability to understand the implicit principles behind certain types of causal systems, to work with abstract symbols such as mathematical figures and symbols, to link pieces of information to each other and to create interrelationships.

3) Spatial/Visual Intelligence: The ability to portray the spatial world internally in one's mind, such as through visual arts, cartography, navigation, engineering, and games that require coordination.

4) Physical/Motor Intelligence: The ability to use the body to perform physical actions and to express physical control, such as when playing a game, producing something, and reaching out to solve a problem.

5) Musical Intelligence: The ability to recognize and use pitch/rhyme, weight and sound patterns, and the ability to distinguish sounds between that of a human's voice and musical instruments.

6) Interpersonal Intelligence: The ability to work cooperatively with others in a small group as well as the ability to communicate and interact with others efficiently.

7) Intrapersonal intelligence: The ability to assess internal emotions, the extent of their emotional responses, stages of thinking, and forces of motivation.

8) Natural Intelligence: The ability to distinguish patterns in nature, classify objects, sense other forms in the world of nature, and to understand and become harmonious with different creatures.

9) Existential intelligence: The ability to recognize and conceptualize ideas at large, as well as, the tendency to raise questions and beliefs about the world around them (Silver, Strong, Perini, 1997) (Hussein, 2003). 
Multi-disciplinary intelligences open up a wide range of educational teaching strategies, which can be applied in the classroom. Gardner's theory suggests that there is no single set of strategies that suits all students at all times. All learners have different talents in multiple types of intelligence; therefore, a particular teaching strategy may seem very successful for one group of students, while unsuccessful for other groups. For example, the texts of books that enable teachers to use the poetic weight, chanting as an educational tool, will notice that students who love music will enthusiastically respond well to this method, unlike students who do not respond to such a strategy in as high degree. In the same context, the provision of images and shapes in books will affect a large array of students affected by space. However, perhaps they will affect differently those students who have a different orientation more toward linguistics or physical impact (Lala 2015, Mahmoud, 2009).

Development of Multiple Intelligences:

Gardner suggested that the individual can innovate well in one of the types of multiple intelligence, and have weak performances in other intelligence areas. This is in accordance with the theory of multiple intelligences where he believes that man has a number of capacities and they may interact with each other. However, they may act in isolation from other abilities, and each kind of intelligence may be the center of creative abilities of the individual (Gardner, 1993).

The growth of multiple intelligences depends on three main factors according to Jabir (2004).

1 - Biological instinct: includes the genetic factors, and any damage to the brain before, during, and after birth.

2. Personal history: takes account of experiences with parents, teachers, relatives and friends who may either further activate the intelligences or prevent their growth.

3- Cultural and historical background: includes space and time, where and when the individual grows up, and the nature of the cultural and educational developments to which the individual is exposed. This is the case in which educational systems can work to develop the intelligences of learners.

The importance of Gardner 's theory of multiple intelligence is that it has a significant role to play in the educational field of intelligence and that has been confirmed. the $\mathrm{P}$ a Alitha It leads to educators being able to improve the level of achievement of students. It raises their concerns about educational content levels, as well as, the possibility of using multiple intelligences to inform teaching methods (Pleasure, 2010). Therefore, in the training of multiple intelligences development it is important to encourage students to create logical links, mental and social alike. To develop socially, for example, encourage students to create links with their local community by adding their voice to the community, and to establish positive relationships among themselves. This was confirmed by Gardner in the theory of multiple intelligences when talking about the intelligence of community and its relationship with the patterns in a culture. and the need to be accompanied by Learning the social value of creative activities in any culture leads to taking a privileged position there (Kienzler, 2001).

The role of multiple intelligences in achieving quality of learning:

Afana and Khazbdar (2004) and Hussain (2005) reported that the theory of multiple intelligences seeks to enhance the overall quality of education and teaching through:

1. Total Quality in Teacher Performance: The theory of multiple intelligences helps the teacher to understand his tasks and roles in preparing materials related to the different personalities of learners and their development according to the type of intelligence that characterizes each learner. This gives the educational process greater quality.

2-The overall quality of the learner's performance and activities : The theory of multiple intelligences helps the learner to understand himself, and determine the roles correctly, and how to deal with both the teacher and the decision, and learning methods of colleagues to maximize the benefit of the learning process .

3-Total Quality in Teaching Methods: The theory of multiple intelligences contributes to the use of teaching methods that are appropriate for the capabilities and intelligences of different learners, because they provide the learner with alternatives.

4- TQM Methods of Assessment: The theory of multiple intelligences depends on multiple methods of evaluation or assessment due to the diversity of fields of intelligence. The focus is directly on the measurement tools appropriate to the type of intelligence to be measured or identified in the learner.

Previous Studies of Multiple Intelligences:

With regard to previous studies, Mahmoud and Mahrama (2014) conducted a study aimed at identifying the level of multiple intelligences of teachers of special education schools in Jordan. The sample consisted of 501 teachers. The 
results showed that the level of multiple intelligences among special education teachers was average and there were no differences due to the variable of sex. There were differences according to the variable of scientific qualifications.

Soman (2014) conducted a study aimed to determine the level of multiple intelligences for teachers of Arabic language at the basic stage in Jordan and its relationship to the expertise and scientific qualifications of the teachers. The sample was 92 teachers, and the results showed that the multiple intelligences of the teachers level was moderate degree, except music intelligence was low. There were no differences found in the variables of experience and scientific qualification in the field of multiple intelligences.

A study in King Abdullah II Schools of Excellence in Jordan, her solicitude (2010) was aimed at learning the degree to which teachers use the strategies of multiple intelligences theory. The study sample consisted of all teachers in those schools and adult Add»m (174) teachers, and study that Oz Harte teachers use King Abdullah II Schools of Excellence is not a theory of multiple intelligences strategies with a high degree. There was an absence of differences because of the impact of sex as a variable.

A Carpenter study (2010) has its DVT to detect the level of multiple intelligences among members of Prepare T. Drees Science of the Faculty of Science at Umm Al Qura University in Saudi Arabia and Ri P for teaching skills met him as they are for a creative and A study sample consisted of all the teachers, and Add $\triangleleft \mathrm{m}$ (12). A member of the faculty from all disciplines of science were used for the first two tools a scale survey of multiple intelligences and a second Q Tabanh, The results showed that the averages of multiple intelligences for members of the faculty were as follows: logical /Mathematical intelligence, self-intelligence, verbal /Linguistic intelligence, social intelligence, visual intelligence/Spontaneous, natural /Environmental intelligence, physical/motor or Kinetic intelligence, and musical/Rhythm intelligence.

Tractor's DVT study (2006), was done to determine the level of multiple intelligences among managers in secondary schools in Jordan, and their relationship with the practice of school management methods. The study sample consisted of (100) directors and (500) teachers from the school community. Two tools were used in the study, the first being the McKenzie scale to measure the level of multiple intelligences of managers, and the second was the questionnaire. The sample was chosen in a random stratified sample. Results showed that managers possessed high rates of self, social, physical and logical intelligence, and scored low in the intelligence types: natural, visual, linguistic, and music. The results also showed the existence of differences in the level of multiple intelligences in regard to gender, experience and pain of scientific Ahl.

DVT study An important study by Douglas, Burtan \& Durham, (2008) was conducted to find out the effect of the use of the theory of multiple intelligences in teaching and the achievement of eighth grade students in mathematics. The sample consisted of (57) students from Amrik, The results showed the existence of differences in student achievement was because of the strategy of teaching using the theory of multiple intelligences.

Al Balhan (2006) did a study of $t$ to measure the effectiveness of the use of multiple intelligences theory methods to improve the academic achievement for reading among a sample of students from middle school in Kuwait who suffer from ??? T. Dunn $\mathrm{j}$ in the collection of academic reading is due to difficulties in reading and so they receive strengthening by doing evening reading lessons. The sample was (200) students who were randomly assigned to two groups. The control group were given their tutoring in the evening by traditional methods. The experimental group studied using the theory of multiple intelligences methods applied to the list of Al matter survey of multiple intelligences of McKenzie (1999), The results related to heart Oz impact of the educational program on academic achievement in reading exceeds the experimental group compared to the GTA collection of members of the control group in the dimensional measurement. valuation As for the effect of the variable, type of school, superior results were Oz Heart School students for female students in the public schools. As for the gender variable, the results of females were higher than the results of males in post-measurement.

Gunst ( 2004) conducted a descriptive study to determine Atja Hat and teachers use multiple intelligences, The study sample was from (622) teachers of the eighth grade for schools of for basic in America, was used w for the Th measurements in this study are: a questionnaire to measure multiple intelligences, and the questionnaire measured for teaching patterns, and a short demographic questionnaire. and Oz results heart that teachers in the study had a tendency to follow logical/mathematical intelligence, wa's social, spiritual and natural intelligences. They did not tend to use linguistic, verbal, spatial, motor, and musical intelligences. Teachers showed a deficiency in the use of language or verbal intelligence, and results showed that teachers have their high average $\mathrm{j}$ For some types of bonding her 
intelligence, and the reason for this is that the teachers are aware of thus Zka Astkhaddmo in Nha ask their teaching.

the strengths

of allegiance and

A study in America by Shearer (2002 aimed at assessing a teacher's capacity for development using multiple intelligences which included first a two-stage evaluation of $\mathrm{M}$ for teachers St., and secondly implementation of a pilot project on how to use in the classroom the teacher's multiple intelligences. The study was conducted in collaboration with a sample of teachers from six (6) schools, and included a sample in the study of $(3,070)$ male and female students in middle and high school. It was noted the results that can educate teachers weak points are multiple Balzkaouat and Amaaljt ha, and the ability of teachers to accommodate multiple intelligences was of importance in the students' intellectual creativity, as well as, the harmony and interaction with the pilot program and Chja For him .

Comment on previous studies

A review of previous studies indicates that those studies have identified the importance of using strategies and programs based on the theory of multiple intelligences in the teaching and ultimately the achievement of students such as in the studies by Carpenter (2010) and Douglas, Burtan \& Durham (2008). The results of the studies showed the superiority of the experimental groups over the control groups, and studies on the need for the interest in the use of strategies and programs urged the list of $\mathrm{Al} \mathrm{Z}$ 's theory of multiple intelligences, as in the study of Al-Najja (2010) and Tractor, (2006), The researcher from the relevant studies in reaching a theoretical background has benefited, and open the horizon for other studies and references to related parties, and also benefited when the study is to develop a tool and methodology and then discuss the results.

What distinguishes this study from previous studies is that it is dealing with the detection of the level of multiple intelligences among deaf adult students in Al Ain University of Science and Technology and the University of Tabuk. They are studies in two universities in two states, $\mathrm{p}$ for a Ge of multiple intelligences with the variables gender, university and work, through the development of the researcher 's M using Mckenzie (1999) scales to measure the level of multiple intelligences which is one of the agreed global standards.

Study Problem:

In view of the importance of the theory of multiple intelligences in the field of education, and because this theory confirms that the student needs to be taught the subject matter through diversified methods which develop the aspects of different intelligences this study was undertaken with deaf students. Knowledge of the multiple intelligences that characterize students in general and deaf students in particular allows one to address and develop their intelligences by the preparation of materials and by the use of varied approaches when teaching students. The problem of studying the level of multiple intelligences among adult deaf students at Al Ain University and Tabuk University is determined from their point of view in light of the above and the study problem can be formulated in the following questions:

Study Questions:

The first question: Are there any statistically significant differences at the level of significance $(\mathrm{a} 005,0)$ in the level of multiple intelligences of adult deaf students at Al Ain University and Tabuk University due to sex as a variable (male, female)?

The second question: Are there significant differences at the level of significance $(\mathrm{a} 005,0)$ in the level of multiple intelligences among adult deaf students at Al Ain University and Tabuk University from their point of view due to the variable of university or place i.e. Al Ain or Tabuk?

The third question: Are there significant differences at the level of significance $(a 005,0)$ at the level of multiple intelligences of adult deaf students at Al Ain University and Tabuk University, from their point of view, attributable to employment (employee or non-employee) as a variable?

Objectives of the study: The study aims to:

1-Recognition of level of multiple intelligences among the students of deaf adults in Al Ain University and the University of Tabuk from their point of view due to gender (male, female).

2- Recognition of the level of multiple intelligences among deaf adult students at Al Ain University and Tabuk University from their point of view attributed to the University (Al-Ain University or Tabuk University) 
3- To know from their point of view if the level of multiple intelligences among adult deaf students in Al Ain University and the University of Tabuk is affected by the status of employment (employees, non-employee).

- Significance of the Study: The importance of this study stems from several aspects:

-The multiple intelligences of deaf students positively affect their learning methods and strategies accordingly .

-The multiplicity of intelligences and their differences among the deaf students requires the adoption of a variety of educational approaches to achieve communication with all the learners present in the classroom. The educational system until recently had neglected many abilities of and possibilities for learners Gardner (1993).

- The theory of multiple intelligences offers its greatest contribution to education by suggesting that teachers need to expand their repertoire of methods, tools and strategies beyond the normal linguistic and logical aspects commonly used in classrooms .

- Students have unique patterns of strengths and weaknesses in different capacities; therefore, it is necessary to understand and develop appropriate tools for use with each student to increase comprehension.

- Limitations of the study: This study was limited to the following determinants:

1- Deaf adult students in Al Ain University and the University of Tabuk enrolled in the second semester during the 2018-2019 academic year.

2- The study tool in terms of its veracity and stability.

-Definitions:

Multiple Intelligences: A theory developed at Harvard University as a result of research conducted by a team of researchers led by Gardner (1983). This theory states that man is capable of learning in multiple ways. Gardner sees that there are several types of intelligence, not just one kind. One uses different types of intelligence when solving problems and in the production of new things according to Abu Eita, (2011).

The level of multiple intelligences: The level is the degree to which gets Al guardian teachers talented in the Qassim region, in every area of MI not t the developer scale and based evaluator of $\mathrm{Q}$ (Multiple Intelligences, Walter McKenzie 1999). Used in this study according to Gardner's classification, to measure the teacher's multiple and varied mental abilities. It includes a measure of eight types of intelligence i.e.: logical intelligence/Mathematical, verbal intelligence/Linguistic, visual intelligence/Spatial, musical intelligence/Rhythmic, physical intelligence/Kinetic, self intelligence/Interior, social intelligence/Outer, and natural intelligence/Environment Gardner (1983).

Deaf students: The deaf person from the medical point of view is one who is deprived of the sense of hearing from birth to the point of making speech operative, for which hearing is impossible with or without hearing aids, or is the one who has audio capability before learning to speak., with that a person can perceive blows Or looking at an airplane passing over his head, However, from the educational, psychological and social point of view he is considered deaf if he cannot understand the words Hamdash and Zallal (2015).

The definition of procedural: are male students and females enrolled in studying as an undergraduate at $\mathrm{Al}$ Ain University in the United Arab Emirates, who were classified as $\mathrm{m}$ deaf based on the Public $\mathrm{m}$ in the foundation of education that have been diagnosed are there.

The Limits of the Study:

-Time Limits: The study sample was in the second semester of 2018-2019.

-Spatial boundaries: The application of the study was limited to Al Ain University in the United Arab Emirates and Saudi Arabia.

-Study tool: The method used to measure the level of creative self-efficacy, which was developed to fit the environment, and verification of its psychometric properties.

Community and Study:

The study population consisted of all the students both deaf males and females $w$ in Al Ain University in the United Arab Emirates, and the University of Tabuk in Saudi Arabia. The study sample shall be a total of (82) students made up of two groups. Al Ain University of Science and Technology Students had (32) distributors (1 2) Student ) 11. Tabuk University had (50) students distributed to (23) students and (27) Students, were selected in the sample intentionality during the academic year (2018/2019) and the reason for choosing the sample intentionality because students who taught them researchers, have shown a willingness to answer the study tool, and 
the presence of understanding management and collaborating to apply the study to the study sample, and (Table 1 ) shows the distribution of Subjects by Study Variables.

Table (1) Distribution of Study Sample Members by Variables

\begin{tabular}{|c|c|c|c|}
\hline Variables & Levels & Total & Percentage \\
\hline \multirow{2}{*}{ Sex } & Male & 44 & $53 \%$ \\
\cline { 2 - 4 } & Female & 38 & $47 \%$ \\
\hline \multirow{2}{*}{ The } & Al-Ain University & 32 & $39 \%$ \\
\cline { 2 - 4 } & Tabuk University & 50 & $61 \%$ \\
\hline \multicolumn{2}{|c}{ Total } & 82 & $100 \%$ \\
\hline
\end{tabular}

Ed uh study:

Use of the researcher in this study measure Walter Mackenzie (Mckenzie, 1999) To measure the level of multiple intelligences by the classification of Gardner, multiple among the students of deaf in Al Ain University and the University of Tabuk, and consists of the scale of nine Mja 's data provided for teachers, and includes all $\mathrm{mg}$ of for one type of types of multiple intelligences, it took multiple intelligences tool final image of (80) Paragraph to measure the intelligences of the pleasures specified and divergent, to include ten paragraphs of each area of multiple intelligences, having been deleted intelligence existentialist, the difficulty of becoming a measure for the instrument of limitations on the eight intelligences A 's core by classification Gardner (Gardner, 1983)

\section{Rationing measure intelligences multiple on p J NH deaf adults in Saudi Arabia and the United Arab Emirates}

\section{- Tool Validation:}

To verify the reliability of a tool it was presented panel of judges with jurisdiction, consisted of nine arbitrators with experience and competence of workers and supervisors in the field of special education for deaf students., distributors as follows ( 3 members of staff teaching at the University Al Ain y, 3 of Members of the faculty of Tabuk University, and 3 supervisors and teachers with deaf students, and asked them to express their opinions on the scale, in order to determine the validity of the expressions of the tool, its clarity and the integrity of its linguistic formulation and its representation of the purpose for which it was built, Then the researcher to conduct infringement for data that suggested her Arbitrators, which centered on the extent of paragraphs compatibility with the area you put into it, and as a nation drafting paragraphs language, as has been amended wording of some paragraphs in terms of construction and language proofreader, and was taking all the notes.

And was by Pearson correlation coefficient between the average performance on the dimension and the average overall performance table shows the sincerity of the tool: 
The Level of Multiple Intelligences of Deaf Adult Students at Al-Ain University and The University of Tabuk

\begin{tabular}{|c|c|c|c|c|c|c|c|c|c|c|}
\hline & & DI & D2 & D3 & D4 & D5 & D6 & D7 & D8 & TOTAL MEAN \\
\hline DI & $\begin{array}{l}\text { Pearson Correlation } \\
\text { Sig. (2-tailed) } \\
\mathrm{N}\end{array}$ & 82 & $\begin{array}{l}.608^{* *} \\
.000 \\
82\end{array}$ & $\begin{array}{l}519^{* *} \\
.000 \\
82\end{array}$ & $\begin{array}{l}.20 * \\
.047 \\
82\end{array}$ & $\begin{array}{l}.674 * \\
.000 \\
82\end{array}$ & $\begin{array}{l}4.66^{*} \\
.000 \\
82\end{array}$ & $\begin{array}{l}0.599= \\
.000 \\
82\end{array}$ & $\begin{array}{l}.99 \\
374 \\
82\end{array}$ & $\begin{array}{l}.717^{*} \\
.000 \\
82\end{array}$ \\
\hline D2 & $\begin{array}{l}\text { Pearson Correlation } \\
\text { Sig. (2-tailed) } \\
\mathrm{N}\end{array}$ & & 82 & $\begin{array}{l}.351 * \\
.000 \\
82\end{array}$ & $\begin{array}{l}.277= \\
.040 \\
82\end{array}$ & $\begin{array}{l}.73= \\
.000 \\
82\end{array}$ & $\begin{array}{l}529 * \\
.000 \\
82\end{array}$ & $\begin{array}{l}529 * \\
.000 \\
82\end{array}$ & $\begin{array}{l}.091 \\
.415 \\
82\end{array}$ & $\begin{array}{l}.713^{*=} \\
.000 \\
82\end{array}$ \\
\hline D3 & $\begin{array}{l}\text { Pearson Correlation } \\
\text { Sig. (2-tailed) } \\
\mathrm{N}\end{array}$ & & & 82 & $\begin{array}{l}.221 * \\
.046 \\
82\end{array}$ & $\begin{array}{l}529^{* *} \\
.000 \\
82\end{array}$ & $\begin{array}{l}.637^{* *} \\
.000 \\
82\end{array}$ & $\begin{array}{l}.482 * \\
.000 \\
82\end{array}$ & $\begin{array}{l}.029 \\
.798 \\
82\end{array}$ & $\begin{array}{l}.692 *= \\
.000 \\
82\end{array}$ \\
\hline D4 & $\begin{array}{l}\text { Pearson Correlation } \\
\text { Sig. (2-tailed) } \\
\mathrm{N}\end{array}$ & & & & 82 & $\begin{array}{l}.316 * \\
.004 \\
82\end{array}$ & $\begin{array}{l}.413 * \\
.000 \\
82\end{array}$ & $\begin{array}{l}.197 \\
.076 \\
82\end{array}$ & $\begin{array}{l}428 * \\
.000 \\
82\end{array}$ & $\begin{array}{l}587^{* *} \\
.000 \\
82\end{array}$ \\
\hline D5 & $\begin{array}{l}\text { Pearson Correlation } \\
\text { Sig. (2-tailed) } \\
\mathrm{N}\end{array}$ & & & & & $\begin{array}{l}1 \\
82\end{array}$ & $\begin{array}{l}712 * \\
.000 \\
82\end{array}$ & $\begin{array}{l}7.30^{* *} \\
.000 \\
82\end{array}$ & $\begin{array}{l}.260 * \\
.019 \\
82\end{array}$ & $\begin{array}{l}.842 * \\
.000 \\
82\end{array}$ \\
\hline D6 & $\begin{array}{l}\text { Pearson Correlation } \\
\text { Sig. (2-tailed) } \\
\mathrm{N}\end{array}$ & & & & & & 82 & $\begin{array}{l}.805^{* *} \\
.000 \\
82\end{array}$ & $\begin{array}{l}.300 * \\
.006 \\
82\end{array}$ & $\begin{array}{l}.831^{* *} \\
.000 \\
82\end{array}$ \\
\hline D7 & $\begin{array}{l}\text { Pearson Correlation } \\
\text { Sig. (2-tailed) } \\
\mathrm{N}\end{array}$ & & & & & & & 82 & $\begin{array}{l}.133 \\
.232 \\
82\end{array}$ & $\begin{array}{l}.732 * \\
.000 \\
82\end{array}$ \\
\hline D8 & $\begin{array}{l}\text { Pearson Correlation } \\
\text { Sig. (2-tailed) } \\
\mathrm{N}\end{array}$ & & & & & & & & 82 & $\begin{array}{l}.463 * \\
.000 \\
82\end{array}$ \\
\hline $\begin{array}{l}\text { TOTAL } \\
\text { MEAN }\end{array}$ & $\begin{array}{l}\text { Pearson Correlation } \\
\text { Sig. (2-tailed) } \\
\mathrm{N}\end{array}$ & & & & & & & & & $\begin{array}{l}1 \\
82\end{array}$ \\
\hline
\end{tabular}

** Correlation is significant at the 0.01 level (2-tailed).

* Correlation is significant at the 0.05 level (2-tailed).

The above table indicates that correlation coefficients are statistically significant except for the correlation between the eighth dimension with the first dimension and the second with the seventh dimension.

Stability of the tool

Krambach's alpha coefficient was 0.93, and the average performance was as follows: 1-1.66 Low, 1.661-2.33 Medium, 2.331-3 High 
Descriptive Statistics

\begin{tabular}{|c|c|c|c|c|c|c|c|}
\hline & $\mathrm{N}$ & Minimum & Maximum & Mean & Std. Deviation & Variance & Rate \\
\hline VAR00007 & 82 & 1.00 & 3.00 & 2.5732 & 54502 & .297 & high \\
\hline VAR00008 & 82 & 1.00 & 3.00 & 2.0610 & .75926 & .576 & Average \\
\hline VAR00009 & 82 & 1.00 & 3.00 & 2.1829 & 6.5032 & .423 & Average \\
\hline VAR00010 & 82 & 1.00 & 3.00 & 2.6707 & 52246 & .273 & high \\
\hline VAR00011 & 82 & 1.00 & 3.00 & 2.2561 & .66316 & .440 & Average \\
\hline DI & 82 & 1.60 & 3.00 & 2.3488 & .38466 & .148 & high \\
\hline VAR00013 & 82 & 1.00 & 3.00 & 2.2561 & 7.5049 & .563 & Average \\
\hline VAR00014 & 82 & 1.00 & 3.00 & 1.9390 & .72602 & .527 & Average \\
\hline VAR00015 & 82 & 1.00 & 3.00 & 2.2439 & 0.61986 & .384 & Average \\
\hline VAR00016 & 82 & 1.00 & 3.00 & 1.9878 & 69378 & .481 & Average \\
\hline VAR00017 & 82 & 1.00 & 3.00 & 2.1829 & .66903 & .448 & Average \\
\hline D2 & 82 & 1.00 & 3.00 & 2.1220 & 0.46375 & .215 & Average \\
\hline VAR00019 & 82 & 1.00 & 3.00 & 2.3537 & .67352 & .454 & high \\
\hline VAR00020 & 82 & 1.00 & 3.00 & 2.5000 & 70711 & .500 & high \\
\hline VAR00021 & 82 & 1.00 & 3.00 & 2.3415 & .72384 & .524 & high \\
\hline VAR00022 & 82 & 1.00 & 3.00 & 2.4390 & 68669 & .472 & high \\
\hline VAR00023 & 82 & 1.00 & 3.00 & 2.5366 & 61253 & .375 & high \\
\hline D3 & 82 & 1.00 & 3.00 & 2.4341 & .47433 & .255 & high \\
\hline VAR00025 & 82 & 1.00 & 3.00 & 1.8171 & 78768 & .620 & Average \\
\hline VAR00026 & 82 & 1.00 & 3.00 & 2.3293 & .72102 & .520 & Average \\
\hline VAR00027 & 82 & 1.00 & 3.00 & 2.0610 & 0.80657 & .651 & Average \\
\hline VAR00028 & 82 & 1.00 & 3.00 & 2.3902 & 0.78183 & 611 & high \\
\hline VAR00029 & 82 & 1.00 & 3.00 & 2.4146 & .76902 & .591 & high \\
\hline D4 & 82 & 1.00 & 3.00 & 2.2024 & 0.57905 & .335 & Average \\
\hline VAR00031 & 82 & 1.00 & 3.00 & 2.5000 & 6.3343 & .401 & high \\
\hline VAR00032 & 82 & 1.00 & 3.00 & 2.3659 & 0.69411 & .482 & high \\
\hline VAR00033 & 82 & 1.00 & 3.00 & 2.0976 & .67786 & 4.60 & Average \\
\hline VAR00034 & 82 & 1.00 & 3.00 & 2.6585 & .50233 & .252 & high \\
\hline VAR00035 & 82 & 1.00 & 3.00 & 2.2073 & 7.3262 & .537 & Average \\
\hline D5 & 82 & 1.00 & 3.00 & 2.3659 & 46167 & .213 & high \\
\hline VAR00037 & 82 & 1.00 & 3.00 & 2.5732 & 66723 & .45 & high \\
\hline
\end{tabular}


The Level of Multiple Intelligences of Deaf Adult Students at Al-Ain University and The University of Tabuk

\begin{tabular}{|c|c|c|c|c|c|c|c|}
\hline VAR00038 & 82 & 1.00 & 3.00 & 2.3659 & 6.3852 & .408 & high \\
\hline VAR00039 & 82 & 1.00 & 3.00 & 2.1220 & .80722 & .652 & Average \\
\hline VAR00040 & 82 & 1.00 & 3.00 & 1.7927 & 7.4928 & 61 & Average \\
\hline VAR00041 & 82 & 1.00 & 3.00 & 2.4390 & 6.4974 & .222 & high \\
\hline D6 & 82 & 1.00 & 3.00 & 2.2585 & 0.47192 & .223 & Average \\
\hline VAR00043 & 82 & 1.00 & 3.00 & 2.6098 & .60361 & 364 & high \\
\hline VAR00044 & 82 & 1.00 & 3.00 & 2.2927 & 71125 & 506 & Average \\
\hline VAR00045 & 82 & 1.00 & 3.00 & 2.4756 & 6.7083 & .450 & high \\
\hline VAR00046 & 82 & 1.00 & 3.00 & 2.4146 & 6.6576 & .443 & high \\
\hline VAR00047 & 82 & 1.00 & 3.00 & 2.7683 & 0.52819 & .279 & high \\
\hline D7 & 82 & 1.40 & 3.00 & 2.5122 & .40867 & .167 & high \\
\hline VAR00049 & 82 & 1.00 & 3.00 & 1.7073 & .76154 & .580 & Average \\
\hline VAR00050 & 82 & 1.00 & 3.00 & 1.6220 & 71389 & .105 & Average \\
\hline VAR00051 & 82 & 1.00 & 3.00 & 1.9268 & 0.84299 & 711 & Average \\
\hline VAR00052 & 82 & 1.00 & 3.00 & 1.6585 & .75718 & .57 & Low \\
\hline VAR00053 & 82 & 1.00 & 3.00 & 1.5000 & 6.8943 & .475 & Low \\
\hline D8 & 82 & 1.0 & 3.0 & 1.683 & 5515 & .304 & Average \\
\hline TOTAL MEAN & 82 & 11.40 & 23.00 & 17.9268 & 2.61005 & 6.812 & \\
\hline Valid N (listwise) & 82 & & & & & & \\
\hline
\end{tabular}

- How to correct the meter:

I took the multiple intelligences tool photographed her the Nha Vision, and ensured that each type of intelligence used ten paragraphs to describe the behavior of that intelligence. This included a for testing as a whole (80) paragraphs, and given each paragraph from zero to two and two, sets her teacher gifted as far as they apply and express his abilities Alzkaiah, so that it becomes Ala for a Meh maximum for each intelligent (20) degrees, and the maximum of the scale as a whole being (160) degrees. had been given instructions a to answer this a for tool for teachers of gifted before a to answer the paragraphs for the tool.

To judge the levels of multiple intelligences of deaf students at Al Ain University and Tabuk University, the score of each field and class was extracted by subtracting the mathematic mean from the class and dividing the output by the standard deviation thereafter. Each level of multiple intelligences was divided into For Ath levels: Low (1-1.66 ), Average (1.661-2.33) and High (2.331-3).

\section{- Study variables}

First: independent variables

- Gender: Male or Female.

- University: Al-Ain and Technology or Tabuk

- Employment: Employee or Non-employee

Second: the dependent variable:

Multiple Intelligences among the students of deaf adults in Al Ain University and the University of Tabuk, which is expressed in arithmetic averages of the estimates of the sample on the paragraphs of the study tool. 
- Results and discussion of the study:

A question for the first variable: Are there statistically significant differences at the level of significance $(005,0)$ in the level of multiple intelligences of adult deaf students at Al Ain University and Tabuk University attributed to the gender variable (male or female)?

To answer this question, the arithmetical averages, standard deviations and the order of averages were calculated, along with the calculation of frequencies and the percentage of the calculation of the distribution of multiple intelligences levels, as illustrated in the following table.

Table of arithmetical averages, standard deviations and percentage distribution of multiple intelligence levels.

Group Statistics

\begin{tabular}{|ll|l|l|l|l|}
\hline & Gender & $\mathrm{N}$ & Mean & Std. Deviation & Std. Error Mean \\
\hline DI & male & 44 & 2.2545 & 34872 & .05257 \\
& female & 38 & 2.4579 & 3.9975 & .6485 \\
\hline D2 & male & 44 & 2.0045 & 42369 & .06387 \\
& female & 38 & 2.2579 & 0.47626 & .07726 \\
\hline D3 & male & 44 & 2.2773 & 0.49031 & .07392 \\
& female & 38 & 2.6158 & .38732 & .06283 \\
\hline D4 & male & 44 & 2.1000 & 6.5058 & .09808 \\
& female & 38 & 2.3211 & 46392 & .07526 \\
\hline D5 & male & 44 & 2.2909 & 0.51300 & .07734 \\
& female & 38 & 2.4526 & .38255 & .06206 \\
\hline D6 & male & 44 & 2.1409 & .49477 & 0.07459 \\
& female & 38 & 2.3947 & .40932 & .06640 \\
\hline D7 & male & 44 & 2.4409 & 44320 & .06682 \\
& female & 38 & 2.5947 & .35256 & .05719 \\
\hline D8 & male & 44 & 1.700 & .5681 & .0857 \\
& female & 38 & 1.663 & .5385 & .0874 \\
\hline \multirow{2}{*}{ TOTAL MEAN } & male & 44 & 17.2091 & 2.57500 & .38820 \\
& female & 38 & 18.7579 & 2.42606 & .39356 \\
\hline
\end{tabular}


The Level of Multiple Intelligences of Deaf Adult Students at Al-Ain University and The University of Tabuk

A table indicating the presence of a virtual difference by sex variable to see if the difference was statistically tested for the difference between the averages as in the following table:

Independent Samples Test

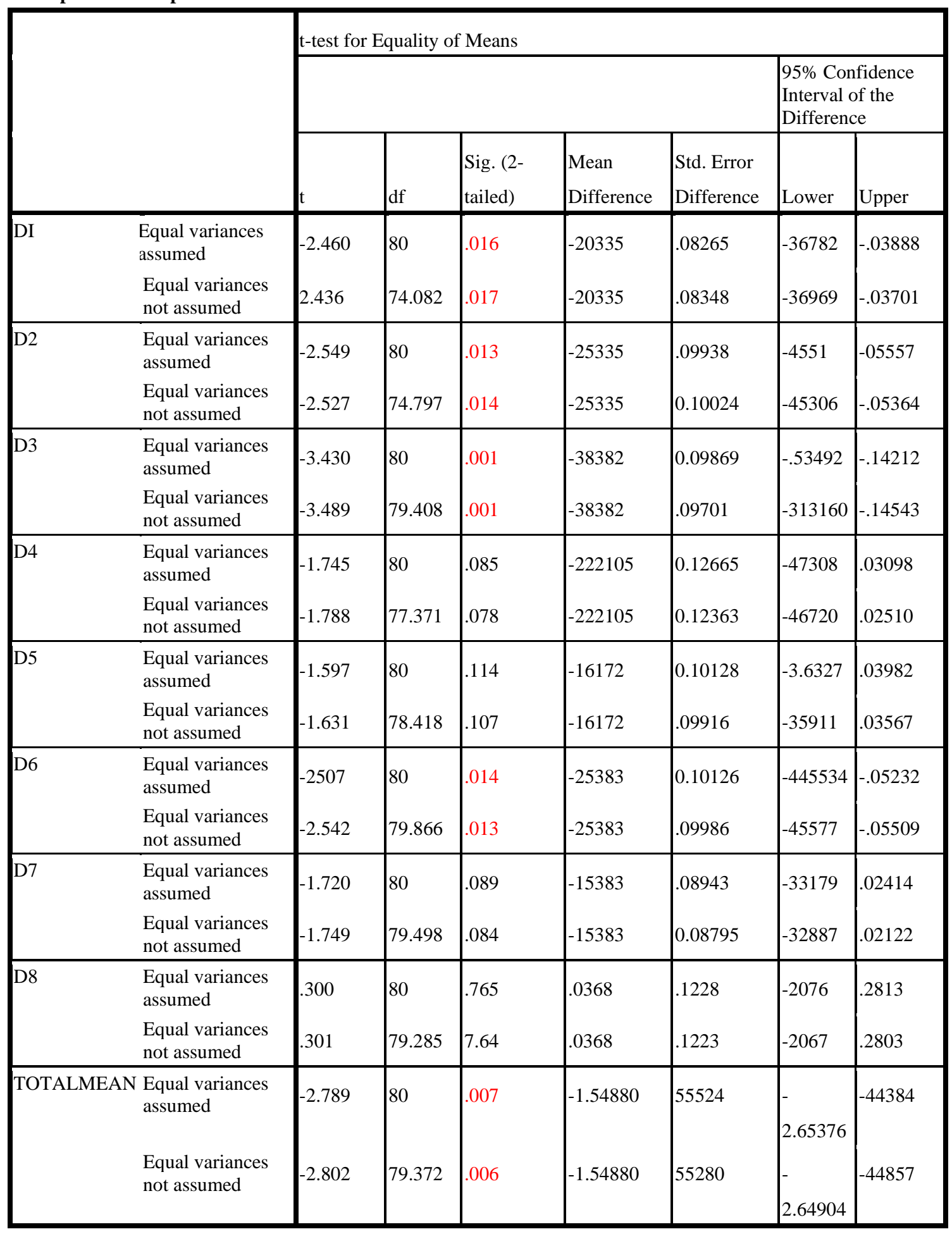


The table indicates statistically significant differences by sex variable in the first, second, third and sixth dimensions, and in the total score and the return to the performance averages to find out the direction of the difference, we find that the difference favors females.

This study is consistent with the study of Tractor (2006), the study of plastic Han Al Balhan (2006), it varies with the study of the beast (2010), and Rasa Al-Najjar (2010). It is noted here that the deaf adults in Al Ain University and the University of Tabuk are characterized by the following multi - Balzkaouat: self intelligence/internal, verbal $\mathrm{IQ} /$ linguistic intelligence, but social/ external, intelligent visual / spatial) and the total score of the scale is in favor of females, and can be explained by high arithmetic average in: self - intelligence / internal, verbal IQ / linguistic intelligence, but social / external, intelligent visual / spatial) of the deaf students of adults in Al Ain University and the University of Tabuk. To their awareness of the importance of this type of intelligences in learning, as well as, increasing the experience and the awareness of and development of an accurate model of self, identifying personal goals, increase self-motivation, perseverance and patience, when females are larger than males.

While there are no significant differences between males and females in the areas of logical / mathematical intelligence, natural / environmental intelligence, physical / motor intelligence, and musical / rhythmic intelligence, depending on the gender variable, this is consistent with stated Gardner by that man has a number of capacities, they may interfere to serve each other, but they may act alone in isolation from other capacity, and every kind of intelligences may be the nucleus of the creative abilities of the individual Gardner (1993).

- The second question: Are there significant differences at the level of significance $(\square 005,0)$ in the level of multiple intelligences among adult deaf students at Al Ain University and Tabuk University done from their point of view because of the university variable ( Al Ain for Science and Technology or Tabuk University )?

To answer to this question was E. due to test (t) for two independent samples and the table below shows the differences in the level of multiple intelligences among students of deaf adults in the Al Ain University and the University of Tabuk from their point of view due to the variable of the university Al Ain University and Tabuk University.

Table $n$ results test $(t)$ differences in the level of multiple intelligences by the teachers of the gifted in the Qassim region from their point of view depending on the variable university 
The Level of Multiple Intelligences of Deaf Adult Students at Al-Ain University and The University of Tabuk

\begin{tabular}{|c|c|c|c|c|c|}
\hline & stat & $\mathrm{N}$ & Mean & Std. Deviation & Std. Error Mean \\
\hline DI & $\begin{array}{l}\text { KSA } \\
\text { UAE }\end{array}$ & $\begin{array}{l}50 \\
32\end{array}$ & $\begin{array}{l}2.3200 \\
2.3938\end{array}$ & $\begin{array}{l}0.37033 \\
.40794\end{array}$ & $\begin{array}{l}.05237 \\
.07211\end{array}$ \\
\hline D2 & $\begin{array}{l}\text { KSA } \\
\text { UAE }\end{array}$ & $\begin{array}{l}50 \\
32\end{array}$ & $\begin{array}{l}2.2240 \\
1.9625\end{array}$ & $\begin{array}{l}.44747 \\
.44991\end{array}$ & $\begin{array}{l}.06328 \\
.7953\end{array}$ \\
\hline D3 & $\begin{array}{l}\text { KSA } \\
\text { UAE }\end{array}$ & $\begin{array}{l}50 \\
32\end{array}$ & $\begin{array}{l}2.3960 \\
2.4938\end{array}$ & $\begin{array}{l}.49237 \\
0.44572\end{array}$ & $\begin{array}{l}.06963 \\
.7879\end{array}$ \\
\hline D4 & $\begin{array}{l}\text { KSA } \\
\text { UAE }\end{array}$ & $\begin{array}{l}50 \\
32\end{array}$ & $\begin{array}{l}2.1240 \\
2.3250\end{array}$ & $\begin{array}{l}.65553 \\
0.58750\end{array}$ & $\begin{array}{l}.07998 \\
0.10386\end{array}$ \\
\hline D5 & $\begin{array}{l}\text { KSA } \\
\text { UAE }\end{array}$ & $\begin{array}{l}50 \\
32\end{array}$ & $\begin{array}{l}2.3400 \\
2.4063\end{array}$ & $\begin{array}{l}0.45040 \\
0.48323\end{array}$ & $\begin{array}{l}.06370 \\
.08542\end{array}$ \\
\hline D6 & $\begin{array}{l}\text { KSA } \\
\text { UAE }\end{array}$ & $\begin{array}{l}50 \\
32 \\
\end{array}$ & $\begin{array}{l}2.2240 \\
2.3125\end{array}$ & $\begin{array}{l}0.44564 \\
0.51290\end{array}$ & $\begin{array}{l}.06302 \\
.09067\end{array}$ \\
\hline D7 & $\begin{array}{l}\text { KSA } \\
\text { UAE }\end{array}$ & $\begin{array}{l}50 \\
32\end{array}$ & $\begin{array}{l}2.5640 \\
2.4312\end{array}$ & $\begin{array}{l}37185 \\
.45468\end{array}$ & $\begin{array}{l}.05259 \\
.08038\end{array}$ \\
\hline D8 & $\begin{array}{l}\text { KSA } \\
\text { UAE }\end{array}$ & $\begin{array}{l}50 \\
32\end{array}$ & $\begin{array}{l}1.668 \\
1.706\end{array}$ & $\begin{array}{l}.5723 \\
5254\end{array}$ & $\begin{array}{l}.0809 \\
.0929\end{array}$ \\
\hline TOTAL MEAN & $\begin{array}{l}\text { KSA } \\
\text { UAE }\end{array}$ & $\begin{array}{l}50 \\
32\end{array}$ & $\begin{array}{l}17.8600 \\
18.0313\end{array}$ & $\begin{array}{l}2.43654 \\
2.89788\end{array}$ & $\begin{array}{l}34458 \\
0.51228\end{array}$ \\
\hline
\end{tabular}

The table indicates that there is a virtual difference and to see if the difference is statistically significant, tests of the difference between the averages were performed 


\section{Independent Samples Test}

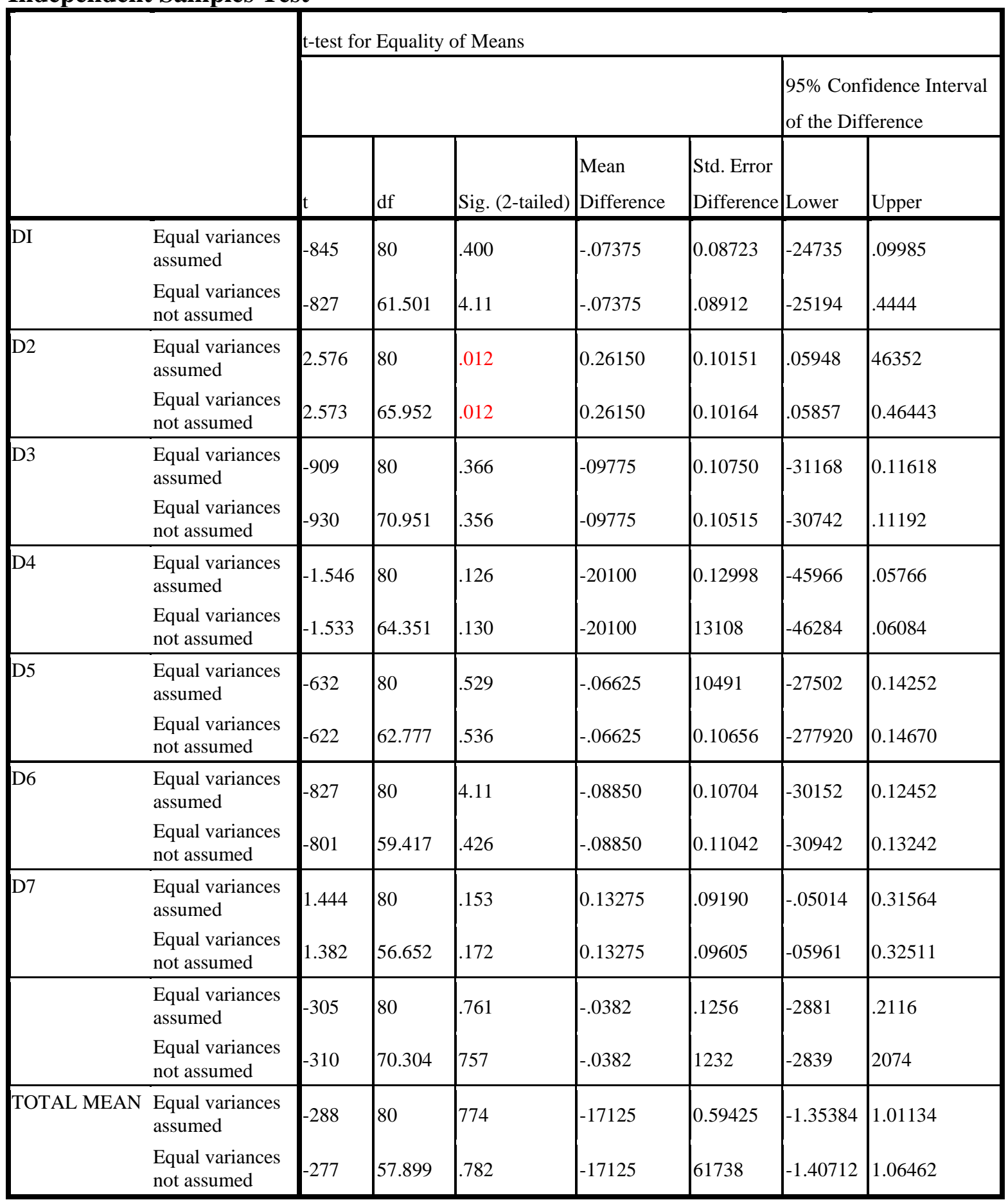




\section{The table indicates that the difference is statistically significant only in the second dimension}

(verbal/linguistic intelligence) to the benefit of adult deaf students at Tabuk University in Saudi Arabia.

This can be attributed to the programs of education for the deaf in Tabuk University in Saudi Arabia compared to their recent experience at Al Ain University for Science and Technology in the Emirates. There was no statistically significant differences in other areas of multiple intelligences, a (self-intelligence, interior intelligence only social/external intelligent, visual/spatial intelligence musical/rhythmic intelligence, logical/mathematical intelligence, physical/ motor intelligence, natural intelligence/IQ Environment). This may be due to the lack of development of these areas for deaf students to be concerned with solving the educational problems and problems of social interaction they face in the society in which they live. The result of this question corresponds to the theoretical guides of the theory of multiple intelligences, in terms of what Armstrong (1994) To that There are several things worth pointing to in the field of multiple intelligences which is that all people have capabilities in each of the types of IQ mentioned. Of course, the abilities of multiple intelligences interact with each other in unique and different ways from person to person. Some people seem to have very high levels of interaction this is Species or Most of them, and some of the other seems to lose Each this is Interactions but have manifestations of the basic types of intelligence mentioned, and holy shows exactly midline between the capabilities of high and sophisticated too, in some types of intelligence, modest in a Some species, and relatively under evolution in a The remaining species ,- The third question: Are there significant differences at the level of significance $(\square 005,0)$ in the level of multiple intelligences of adult deaf students at Al Ain University and Tabuk University from their point of view attributed to employment (employee, non-employee)?- $\quad$ To answer to this question was E. due to test ( $t$ ) for two independent samples and the table below shows the differences in the level of multiple intelligences among students of deaf adults in the Al Ain University and the University of Tabuk from their point of view is due to employment (employee-non-employee)?

To find out if there was a difference in performance according to the employment status variable, the averages were calculated according to the state of employment.Group Statistics

\begin{tabular}{|c|c|c|c|c|c|}
\hline & Job status & $\mathrm{N}$ & Mean & Std. Deviation & Std. Error Mean \\
\hline DI & $\begin{array}{l}\text { employed } \\
\text { unemployed }\end{array}$ & $\begin{array}{l}50 \\
32\end{array}$ & $\begin{array}{l}2.3200 \\
2.3937\end{array}$ & $\begin{array}{l}0.39795 \\
36450\end{array}$ & $\begin{array}{l}0.05628 \\
.6444\end{array}$ \\
\hline D2 & $\begin{array}{l}\text { employed } \\
\text { unemployed }\end{array}$ & $\begin{array}{l}50 \\
32 \\
\end{array}$ & $\begin{array}{l}2.0160 \\
2.2875 \\
\end{array}$ & $\begin{array}{l}42347 \\
0.48176\end{array}$ & $\begin{array}{l}.09899 \\
.08516\end{array}$ \\
\hline D3 & $\begin{array}{l}\text { employed } \\
\text { unemployed }\end{array}$ & $\begin{array}{l}50 \\
32\end{array}$ & $\begin{array}{l}2.3400 \\
2.5813\end{array}$ & $\begin{array}{l}0.48697 \\
0.42001\end{array}$ & $\begin{array}{l}.6887 \\
.07425 \\
\end{array}$ \\
\hline D4 & $\begin{array}{l}\text { employed } \\
\text { unemployed }\end{array}$ & $\begin{array}{l}50 \\
32\end{array}$ & $\begin{array}{l}2.3160 \\
2.0250\end{array}$ & $\begin{array}{l}.54524 \\
59406 \\
\end{array}$ & $\begin{array}{l}0.07711 \\
0.10502\end{array}$ \\
\hline D5 & $\begin{array}{l}\text { employed } \\
\text { unemployed }\end{array}$ & $\begin{array}{l}50 \\
32\end{array}$ & $\begin{array}{l}2.3200 \\
2.4375\end{array}$ & $\begin{array}{l}50629 \\
37824\end{array}$ & $\begin{array}{l}.07160 \\
.06686\end{array}$ \\
\hline D6 & $\begin{array}{l}\text { employed } \\
\text { unemployed }\end{array}$ & $\begin{array}{l}50 \\
32 \\
\end{array}$ & $\begin{array}{l}2.2200 \\
2.3188 \\
\end{array}$ & $\begin{array}{l}.50990 \\
.40595\end{array}$ & $\begin{array}{l}.07211 \\
.07176\end{array}$ \\
\hline D7 & $\begin{array}{l}\text { employed } \\
\text { unemployed }\end{array}$ & $\begin{array}{l}50 \\
32\end{array}$ & $\begin{array}{l}2.4280 \\
2.6438\end{array}$ & $\begin{array}{l}44265 \\
.31206\end{array}$ & $\begin{array}{l}.06260 \\
.05516\end{array}$ \\
\hline D8 & employed & 50 & 1.788 & 5561 & .786 \\
\hline
\end{tabular}




\begin{tabular}{|c|c|c|c|c|c|}
\hline & unemployed & 32 & 1.519 & .5102 & .0902 \\
\hline TOTALMEAN & $\begin{array}{l}\text { employed } \\
\text { unemployed }\end{array}$ & $\begin{array}{l}50 \\
32\end{array}$ & $\begin{array}{l}17.7480 \\
18.2063\end{array}$ & $\begin{array}{l}2.72728 \\
2.43124\end{array}$ & $\begin{array}{l}.38570 \\
0.42979\end{array}$ \\
\hline
\end{tabular}

\section{To find out if the difference is statistically significant}

Independent Samples Test

\begin{tabular}{|c|c|c|c|c|c|c|c|c|}
\hline & \multicolumn{7}{|c|}{ t-test for Equality of Means } \\
\hline & & $\mathrm{t}$ & df & Sig. (2-tailed) & Mean Difference & $\begin{array}{l}\text { Std. Error } \\
\text { Difference }\end{array}$ & \multicolumn{2}{|c|}{$\begin{array}{l}95 \% \text { Confidence } \\
\text { Interval of the } \\
\text { Difference }\end{array}$} \\
\hline DI & $\begin{array}{l}\text { Equal variances } \\
\text { assumed } \\
\text { Equal variances not } \\
\text { assumed }\end{array}$ & $\begin{array}{l}-845 \\
-862\end{array}$ & $\begin{array}{l}80 \\
70.413\end{array}$ & $\begin{array}{l}.400 \\
.392\end{array}$ & $\begin{array}{l}-.07375 \\
-.07375\end{array}$ & $\begin{array}{l}0.08723 \\
.8555\end{array}$ & $\begin{array}{l}-24735 \\
-244436\end{array}$ & $\begin{array}{l}.09985 \\
.9686\end{array}$ \\
\hline D3 & $\begin{array}{l}\text { Equal variances } \\
\text { assumed } \\
\text { Equal variances not } \\
\text { assumed }\end{array}$ & $\begin{array}{l}-2.306 \\
-2.382 \\
\end{array}$ & $\begin{array}{l}80 \\
73.069\end{array}$ & $\begin{array}{l}.024 \\
.020\end{array}$ & $\begin{array}{l}-24125 \\
-24125\end{array}$ & $\begin{array}{l}10463 \\
0.10127\end{array}$ & $\begin{array}{l}-49497 \\
-4.4308\end{array}$ & $\begin{array}{l}-.03303 \\
-.03942\end{array}$ \\
\hline D4 & $\begin{array}{l}\text { Equal variances } \\
\text { assumed } \\
\text { Equal variances not } \\
\text { assumed }\end{array}$ & $\begin{array}{l}2.276 \\
2.234\end{array}$ & $\begin{array}{l}80 \\
62.031\end{array}$ & $\begin{array}{l}.025 \\
.029\end{array}$ & $\begin{array}{l}0.29100 \\
0.29100\end{array}$ & $\begin{array}{l}0.12783 \\
0.13028\end{array}$ & $\begin{array}{l}.03661 \\
.03057\end{array}$ & $\begin{array}{l}.45539 \\
.55143\end{array}$ \\
\hline D5 & $\begin{array}{l}\text { Equal variances } \\
\text { assumed } \\
\text { Equal variances not } \\
\text { assumed }\end{array}$ & $\begin{array}{l}-1.126 \\
-1.199 \\
\end{array}$ & $\begin{array}{l}80 \\
77.984\end{array}$ & .263 & $\begin{array}{l}-17750 \\
-17750\end{array}$ & $\begin{array}{l}0.10434 \\
.9797\end{array}$ & $\begin{array}{l}-32515 \\
-31254\end{array}$ & $\begin{array}{l}.09015 \\
.7754\end{array}$ \\
\hline D8 & $\begin{array}{l}\text { Equal variances } \\
\text { assumed } \\
\text { Equal variances not } \\
\text { assumed }\end{array}$ & $\begin{array}{l}2.208 \\
2.250\end{array}$ & $\begin{array}{l}80 \\
70.338\end{array}$ & $\begin{array}{l}.030 \\
.028\end{array}$ & $\begin{array}{l}2692 \\
2692\end{array}$ & $\begin{array}{l}.1220 \\
.1197\end{array}$ & $\begin{array}{l}.065 \\
.0306\end{array}$ & $\begin{array}{l}5120 \\
.5079\end{array}$ \\
\hline
\end{tabular}


The Level of Multiple Intelligences of Deaf Adult Students at Al-Ain University and The University of Tabuk

\begin{tabular}{|c|c|c|c|c|c|c|c|c|}
\hline TOTAL & $\begin{array}{l}\text { Equal variances } \\
\text { assumed }\end{array}$ & -774 & 80 & .441 & -45825 & .59234 & -1.63705 & 7.2055 \\
\hline MEAN & $\begin{array}{l}\text { Equal variances not } \\
\text { assumed }\end{array}$ & -794 & 71.641 & .430 & -45825 & .7748 & -1.60952 & 69302 \\
\hline
\end{tabular}

The table indicates that the difference D statistically depends on the status of employment in variable fields (IQ verbal/linguistic intelligence, social/external intelligence, natural/ environmental intelligence, physical/motor intelligence, musical/rhythmic intelligence. Differences that arise for non-staff may be explained in that non-staff benefits from having more leisure time where they can practice their sports activities, and develop their talents that fit the areas of multiple intelligences such as: sports, music, getting out in nature, integrating more with the community around them, and participating in the university's various activities. There is more time to participate in the activities of the university or in any other activities. The reason may also be attributed to the high participation of deaf adult students in Al Ain University and Tabuk University in the training courses offered by the universities and other training institutions in Saudi Arabia and the UAE in the field of intelligence that distinguish this category of deaf adult non-employees from adult deaf students.

There are no statistically significant differences for the employment variable (employee, non-employee) for the other areas of multiple intelligences internal/internal intelligence, logical/mathematical intelligence, visual/spatial intelligence. This can be explained by the fact that these multiple intelligences do not require time to develop and strengthen. The result of this question is consistent with Gardner's conclusion:

1. That according to this theory each individual has present the intelligences namely: linguistic, mathematical, logical, physical, personal, social, dynamic, spatial, visual, musical, natural, and existential.

2. That these intelligences operate in independent and varied levels within an individual.

3. The level of multiple intelligences varies from one individual to another, and each individual specializes in a mixture or blend of multiple intelligences. Abdel-Kader, et al., 2008).

Recommendations: In light of the results of the study, it is recommends researcher Wen as follows:

1. Conducting similar future studies on other samples of deaf students in other regions and cities with different economic, social and cultural characteristics.

2. Conduct a similar study for late known on between multiple intelligences levels among teachers of deaf students.

3. Theoretical and practical training of deaf students and their teachers in the different educational areas and how to employ multiple intelligences when working with deaf students.

4. That the teaching strategies be based on the theory of multiple intelligences when teaching educational classes in different stages.

\section{References:}

1. Abu Eita, Jawhara (2011) Multiple Intelligences and Self-efficacy among the 10th Grade Students in the Schools of the Directorate of Education in Zarqa, Journal of Educational Education, No.(3), July .

2. - Zaki, Abdelkader (2000). Teaching centered on learner and learner principles and applications . Girls Education Project in Morocco (MEG) The United States Agency Llt International Numeih (USAID)

3. Shami, Hamdan Mamdouh (2008) Multiple Intelligences and Learning Mathematics Theory and Application, Anglo Egypt Library, Cairo, Egypt .

4. Supervisor, Anshrah (2003) Effectiveness of a proposed program for the development of educational competencies of creative thinking among female students teachers at the Faculty of Kindergarten, unpublished $\mathrm{PhD}$ thesis, Alexandria University, Egypt .

5. Jaber, Jaber Abdul-Hamid (2004) Multiple Intelligences and Understanding Development and deepening, Arab Thought House, Cairo, Egypt .

6. Hussein, Mohamed Abdel Hadi (2005). Introduction to the theory of multiple intelligences . United Arab Emirates : University Book House .

7. Hussein, Mohamed Abdel Hadi (2003). The human brain . Modern University Office, Alexandria, Egypt . 
8. Suman, Ahmed (2014) The Level of Multiple Intelligences for Teachers and Teachers of Arabic Language in the Basic Stage in Jordan and its Relation to Experiences and Scientific Qualifications , An-Najah University Journal of Research ( Humanities ), Vol . 28 , No. 5 , Nablus, Palestine .

9. Hamdash, Sonia, and Zallal, Nasira (2015) Self-Assessment of Deaf Children and Non- Integrated Children in the Normal School (Comparative Field Study), Journal of Social Humanities, No. 19, Algeria .

10. Amer, Tarek, Mohammed, Rabie (2008) Multiple Intelligences, Dar Al Yazuri Scientific Publishing and Distribution, Amman, Jordan

11. Obaidat, Zoukan, Abu Samaid, Suhaila (2005) Brain, Learning and Thinking, Second Edition, Dibono Printing, Publishing and Distribution, Amman, Jordan .

12. Abdul Qadir, Fathi, Abu Hashim, Mr. (2008) construction in light of the global classification and its relationship with all Gardner 's self - efficacy and problem - solving and academic achievement among university students , Journal of the Faculty of Education, University of Zagazig, No. 120 , Cairo, Egypt .

13. Afaneh, Izz, and Khaznadar, Nayla ( 2004 ) Teaching classroom multi - Balzkaouat, Dar march for Publishing and Distribution, Amman, Jordan

14. Mahmoud, Amani, Maharmh, Lena (2014) level of multiple intelligences for teachers of special education schools in Jordan from their point of view , Journal of Educational Sciences Studies, University of Jordan, Vol . 41 , No. (1), Amman, Jordan .

15. Mahmoud, Ahmed (2009) Effect of the use of multiple intelligence theory strategy in the development of critical thinking among the ninth grade students in the field of Islamic education in Jordan, unpublished doctoral thesis, University of Jordan, Amman, Jordan .

16. Najjar, Iyad (2010) The level of multiple intelligences among the faculty of science at Umm Al-Qura University and their relation to their creative teaching skills, 7th Arab Scientific Conference for the gifted and talented, Amman, Jordan

17. dreariness, Nayef (2010) degree teachers use for the strategies of multiple intelligences theory in King Abdullah II in the schools for Jordan, unpublished Master Thesis, Amman Arab University, Amman, Jordan.

18. Foreign References:

19. Al Ballhan, E. (2006). Multiple intelligences styles in relation to

20. improved reading academic performance in Kuwaiti middle school,

21. Middle East Studies, Kuwait University (on line). Available:

22. http:/search.epnet.com/login.aspx.

23. -Armstrong, T. (1994). Multiple intelligence in the classroom. Alexandria: Association for supervision and curriculum Development, Arbor Michigan USA VA: ASCD.

24. Douglas, O. Burtan, K. \& Reese - Durham, N. (2008). The effects of

25. the Multiple Intelligence teaching strategy on the academic

26. Achievement of eight grade math student . Journal of ins-structional

27. psychology, V35, P182-187.

28. Gardner, H. (1983). Frames of Mind: The Theory of Multiple Intelligence. NewYork: basic Books.

29. -Gardner, H. (1993). Creating Minds. New York: Basic Books.

30. Gardner, H. (1987). Developing the spectrum of human intelligence. Harvard Educational Review, 57 (2) .187-193.

31. Gunst, Gary A. (2004). A study of multiple intelligence among

32. Teachers In Catholic elementary schools in Archdiocese of Detroit

33. (Michigan) . DAI-A 65/04, P. 1233. Available at: http: // wwwlib.

34. UMI. com / dissertations

35. Kienzler, Donna (2001). Ethics, Critical Thinking, and Professional Communication Pedagogy. Technical Communication Quarterly, Summer 2001, vol. (1). Issue (3).

36. Mackenzie, W. (1999). Multiple Intelligences Survey. Retrieved online 15/ 10/2013 from the world wide web: http://surfaquarium.com/MI/inventory.htm

37. -Silver, H; Strong, R. and Perini, M. (1997) Integrating learning styles

38. and Multiple Intelligence. Educational Leadership, 55 (1). Pages 22-27 Alexandria VA.

39. Shearer, C. Branton (2002). Using a Multiple Intelligences

40. Assessment to Facilitate Teacher Development . Paper presented at 41. the annual meeting of the American Education Research association. 